\title{
Bone marrow irradiation chimeras in the BB rat: Evidence suggesting two defects leading to diabetes and lymphopoenia
}

\author{
J. Scott ${ }^{1}$, V.H. Engelhard ${ }^{2}$ and D.C. Benjamin ${ }^{2}$ \\ ${ }^{1}$ Departments of Pediatrics and Pharmacology, and ${ }^{2}$ Microbiology, University of Virginia, School of Medicine, Charlottesville, Virginia, USA
}

\begin{abstract}
Summary. A series of bone marrow irradiation chimeras were constructed in an attempt to determine the site of the defect(s) leading to diabetes and/or lymphopoenia in the BB rat. In BB rats that were lethally irradiated and reconstituted with T-cell-depleted Wistar-Furth (WF) rat bone marrow, the incidence of diabetes was reduced, and in animals treated with WF bone marrow at $<44$ days of age, the disease was completely prevented. Such animals demonstrated normal lymphocyte counts in peripheral blood, and normal lymphocyte function (as indicated by mixed lymphocyte response), but retained an abnormal T-cell subset distribution only partially improved above that of diabetes-prone BB rats. The incidence of diabetes in these irradiated chimeras was significantly reduced compared to the indicence in BB rats
\end{abstract}

irradiated at the same age but reconstituted with bone marrow from BB rats. In WF rats that were lethally irradiated and reconstituted with T-cell-depleted bone marrow from overtly diabetic BB rats, no diabetes was induced. Such animals demonstrated normal lymphocyte counts in peripheral blood, normal lymphocyte function, and normal T-cell subset distributions. Overall, these results suggest two defects leading to diabetes and/or lymphopoenia in the BB rat. One of these occurs at the level of the bone marrow stem cell while the other resides in the T-cell differentiative environment.

Key words: Insulin-dependent diabetes, BB rat, immunology, chimeras, bone marrow, lymphopoenia.
The spontaneously diabetic BB rat is currently the best-studied animal model of Type 1 (insulin-dependent) diabetes mellitus. The salient features of the disease in BB rats include an abrupt onset of severe hyperglycaemia, insulinopoenia, glycosuria, and acute ketoacidosis [1]. Histologic study of acutely diabetic animals reveals an intense mononuclear infiltration of the pancreatic islets (insulitis) [2,3], involving mostly activated lymphocytes and macrophages [4]. Obesity is absent, and both sexes are affected equally. The syndrome develops in approximately 70 percent of diabetes-prone rats between 60 and 120 days of age $[1,5,6]$.

There is considerable evidence that diabetes in $\mathrm{BB}$ rats, like human Type 1 diabetes, has an autoimmune aetiology. The BB rat is characterised by multiple abnormalities of humoral and cell-mediated immunity. The insulitis is accompanied by rapid, selective destruction of virtually all pancreatic B cells $[2,3]$. Nonspecies-specific but organ-specific antibodies directed against surface determinants of rat islet cells have been detected in the serum of $\mathrm{BB}$ rats $[7,8]$. In addition, approximately $50 \%$ of these rats develop antibodies to gastric parietal cells and smooth muscle, with concom- itant lymphocytic gastritis [9]. Diabetes-prone BB rats are profoundly $\mathrm{T}$-lymphocytopoenic with reductions of both T-helper/inducer $\left(\mathrm{T}_{\mathrm{h}} / \mathrm{T}_{\mathrm{i}}\right)$ and T-cytotoxic/suppressor $\left(T_{c} / T_{s}\right)$ cell populations [10-12]. As is typical of autoimmunity in other animals, the BB rat shows depressed responsiveness to concanavalin $\mathrm{A}$ (ConA) and to allogeneic stimulator cells in mixed lymphocyte reactions (MLRs) [13, 14].

Evidence that the diabetes in BB rats is T-cell-mediated stems from a number of observations, such as prevention of the disease by neonatal thymectomy [15] or by transfusions of peripheral T-lymphocytes from a diabetes-resistant line of $\mathrm{BB}$ rats [16]. Injection of ConA-activated splenic lymphocytes has been shown to adoptively transfer insulitis and diabetes in young diabetes-prone BB rats [17], or in lines of diabetes-resistant $\mathrm{BB}$ rats and Wistar-Furth (WF) rats that have been pretreated with cyclophosphamide [18]. Neonatal inoculation of diabetes-prone BB rats with bone marrow cells from a normal strain of rat (creating chimeras) prevents diabetes [6,12, 19-21]. In our study [6], mixed lymphocyte cultures and ConA stimulation assays performed with lymphocytes from the recipient 
$\mathrm{BB}$ rats demonstrated that they had been immunologically reconstituted. Diabetes in the BB rat can be prevented or reversed by various immunosuppressive procedures, such as administration of antilymphocyte globulin [22], glucocorticoids [23], or cyclosporin [23-25].

A series of bone marrow irradiation chimeras were constructed $[26,27]$, using various combinations of normal or BB rat recipients and bone marrow donors, in an attempt to determine the site of the defect(s) leading to diabetes and/or T-cell lymphopoenia in the $\mathrm{BB}$ rat. If the defect(s) in $\mathrm{BB}$ rats leading to diabetes and/or T-cell lymphopoenia resides in the lymphoid stem cells, then transplanting these stem cells from diabetes-prone animals into irradiated diabetes-resistant (normal) animals should induce diabetes and/or lymphopoenia. As a corollary, if such defect(s) reside in the lymphoid stem cells, transplanting these stem cells from normal rats into irradiated diabetes-prone animals should prevent the onset of diabetes and/or correct the T-cell abnormalities. Conversely, if the defect(s) resides in the differentiative environment of the T-cell, then transplanting the lymphoid stem cells from diabetes-prone animals into irradiated normal animals would not induce diabetes nor lymphopoenia, and transplanting the stem cells from normal animals into irradiated diabetes-prone animals would not prevent the onset of diabetes nor correct the T-cell abnormalities. The experiments described in this paper were carried out to test these possibilities.

\section{Materials and methods}

\section{Animals}

The Charlottesville BB rat colony was begun in 1982 with breeding pairs from a subline of BB rats with a high incidence of diabetes, generously donated by Dr. Arthur Like (University of Massachusetts) from the parent colony at Worcester, Mass, USA. The original breeding pairs were obtained in their 13th-14th generation of brother-sister inbreeding; the Charlottesville colony has been maintained by random breeding. To preserve genetic homogeneity with the parent colony, additional breeders have occasionally been obtained from the inbred colony at Worcester. The animals for this study were maintained as previously described [6].

Female Wistar-Furth (WF) rats were obtained at 4-5 weeks of age from Harlan Sprague Dawley (Indianapolis, Ind, USA), and maintained in a separate room with food and water ad libitum until used as bone marrow, spleen, or lymph node donors, or as bone marrow recipients. BB rats are derived from a Wistar line and therefore have the same major histocompatibility complex (MHC) haplotype $\left(\mathrm{RT}^{4}{ }^{u}\right)$ as WF rats $[12,28]$.

Female Fisher rats (Charles River Lakeview, Boston, Mass, USA) were selected as a source of allogeneic ( $\mathrm{RT}^{1}{ }^{1}$ ) stimulator spleen cells. These rats were housed under conditions similar to the WF rats.

All irradiated animals were kept for at least 2 months in a PortaRoom dual-flow cleanroom furnished with HEPA filters (Lab-Products, Maywood, NJ, USA). At time of killing, serum samples were collected and stored frozen for later evaluation of nonfasting serum glucose values by the glucose oxidase method using a Beckman Glucose I autoanalyzer (Beckman Instruments, Fullerton, Calif, USA).

\section{Preparation and injection of donor bone marrow cells}

T-cell-depleted bone marrow was prepared as previously described [6]. Marrow from several rats was pooled for inoculation of several recipients. Each recipient was given 800 rads whole-body irradiation from a Theratron- $80^{60}$ cobalt source (Atomic Energy of Canada, Ont, Canada). Irradiated rats each received an intracardiac (i. c.) injection of $5 \times 10^{7}$ viable bone marrow cells (excluding erythrocytes) in a volume of $0.5 \mathrm{ml}$ of Hanks' Balanced Salt Solution (HBSS) without serum, within $6 \mathrm{~h}$ after irradiation. The animals survived the irradiation and bone marrow injection procedures well and returned to normal weight within a few weeks after treatment. All experimental animals were observed for at least 140 days post-inoculation, or until onset of diabetes.

Table 1 lists the bone marrow donors and recipients. A total of 30 adolescent WF rats were chosen for irradiation. Of these, 23 were inoculated with $\mathrm{BB}$ bone marrow derived from overtly diabetic donors; these recipients were designated $\mathrm{BB} \rightarrow \mathrm{WF}$ chimeras. The other $7 \mathrm{WF}$ rats were inoculated with WF bone marrow, as irradiation controls, and were designated $W F \rightarrow W F$ "chimeras". In Experiment I, 39 adolescent diabetes-prone BB rats from 6 litters, ranging in age from 40-109 days, were chosen for irradiation and inoculation with WF bone marrow, and were designated $\mathrm{WF} \rightarrow \mathrm{BB}$ chimeras. In Experiment II, an additional $13 \mathrm{WF} \rightarrow \mathrm{BB}$ chimeras were created, with recipients from 5 litters, ranging in age from 37-40 days; $21 \mathrm{BB} \rightarrow \mathrm{BB}$ animals were created, with recipients from 7 litters, ranging in age from $38-41$ days. As in the $\mathrm{BB} \rightarrow \mathrm{WF}$ chimeras, the $\mathrm{BB} \rightarrow \mathrm{BB}$ animals received bone marrow from overtly diabetic donors.

\section{Assessment of lymphopoenia}

Samples of peripheral blood for differentials and leucocyte counts were collected in EDTA by i.c. puncture of rats mildly anaesthetised with Metofane (Pitman-Moore, Washington Crossing, NJ, USA). The absolute number of leucocytes per litre of blood was determined using a haemocytometer. The number of lymphocytes was calculated from this leucocyte count using data obtained by differential counts on Wright-stained blood cells.

\section{T-cell subset analyses}

Cytofluorographic analyses of spleen cells incubated with the murine-derived monoclonal antibodies W3/13, W3/25, OX 8 , or OX 19 , and a fluorescein isothiocyanate-conjugated anti-murine IgG second

Table 1. Experimental and control rats

\begin{tabular}{|c|c|c|c|}
\hline Donor & Recipient & Designation & $\begin{array}{l}\text { Number } \\
\text { in study }\end{array}$ \\
\hline $\begin{array}{l}\text { Experin } \\
\text { WF }\end{array}$ & WF & $W F \rightarrow W F$ & 7 \\
\hline BB & WF & $\mathrm{BB} \rightarrow \mathrm{WF}$ & 23 \\
\hline WF & BB & $\mathrm{WF} \rightarrow \mathrm{BB}$ & 39 \\
\hline \multicolumn{2}{|c|}{ Untreated BB rats in total colony } & BB & 111 \\
\hline \multicolumn{4}{|c|}{ Experiment II: } \\
\hline & BB & $\mathrm{BB} \rightarrow \mathrm{BB}$ & 21 \\
\hline \multicolumn{2}{|c|}{$\begin{array}{l}\text { Untreated BB littermates of the } \\
\text { irradiation chimeras }\end{array}$} & BB & 21 \\
\hline \multicolumn{2}{|c|}{ Untreated $\mathrm{BB}$ rats in total colony } & BB & 46 \\
\hline
\end{tabular}

After completion of Experiment $\mathrm{I}$, new breeders were acquired for our BB rat colony. BB $\rightarrow$ WF irradiation chimeras were WF rats lethally irradiated and injected with $\mathrm{T}$-cell-depleted bone marrow from overtly diabetic $\mathrm{BB}$ rats; $\mathrm{WF} \rightarrow \mathrm{BB}$ irradiation chimeras were diabetes-prone $\mathrm{BB}$ rats irradiated and injected with T-cell-depleted bone marrow from normal WF rats; $\mathrm{BB} \rightarrow \mathrm{BB}$ and $\mathrm{WF} \rightarrow \mathrm{WF}$ irradiation controls were irradiated and injected with syngeneic T-cell-depleted bone marrow 
antibody, were performed on a fluorescence-activated cell sorter (FACS). These methods have been previously described [6]. The specificities of the monoclonal antibodies were as follows [29-32]: W3/13 - all T-lymphocytes and thymocytes ("pan T"); OX19 - an alternative pan $T$ marker; W3/25 - helper $T$-cells $\left(T_{h}\right)$, inducer T-cells $\left(T_{i}\right)$, and some macrophages; OX 8 - cytotoxic $T$-cells $\left(T_{c}\right)$, suppressor T-cells $\left(T_{s}\right)$, and natural killer cells (NK). In most laboratories, the use of OX19 has largely superceded that of W3/13, since OX19 has been found to label no cells other than thymocytes and peripheral T-cells [33]. The results are expressed as the percent of the total number of cells counted that were positive.

A monoclonal antibody to the RT-7.2 T-cell differentiation alloantigen [34] was used to document the persistence of donor-origin lymphoid cells in the WF $\rightarrow \mathrm{BB}$ chimeras. The RT-7.2 antigen is expressed on WF T-cells, B-lymphocytes, and thymocytes, but is totally missing in $B B$ rat lymphoid cells. Briefly, at the time of killing, spleen cells were removed, washed, and incubated in HBSS supplemented with $1 \%$ bovine serum albumin (BSA) and $0.1 \%$ sodium azide; this incubation medium was designated HBA. The cells were incubated in HBA for $30 \mathrm{~min}$ at room temperature, in the presence of biotinylated anti-RT-7.2, and then washed several times and incubated for $15 \mathrm{~min}$ at room temperature in HBA containing fluorescein-streptavidin (Amersham Corporation, Arlington Heights, Ill, USA). Cells were analysed on the FACS as described for the other monoclonal antibodies.

\section{Assessment of lymphocyte function}

MLRs were performed with lymph node cells and spleen cells from control diabetic $\mathrm{BB}$ rats, control WF rats, and irradiation chimeras $(\mathrm{WF} \rightarrow \mathrm{BB}, \mathrm{BB} \rightarrow \mathrm{WF}$, and $\mathrm{BB} \rightarrow \mathrm{BB})$. The methods used were described previously [6].

\section{Statistical analysis}

All parametric data are presented as mean \pm standard error of the mean (SEM). Probability values ( $p$ ) for differences in incidence of diabetes between experimental groups were calculated using the Fisher's Exact test (two-tailed). Only those animals surviving either to the age of 140 days or to the onset of diabetes were included. The parameters of leucocytes $/ \mu \mathrm{l}$, lymphocytes $/ \mu \mathrm{l}$, segmented cells $/ \mu \mathrm{l}$, the percentages of the various cell types measured by FACS analysis, and the incorporation of ${ }^{3} \mathrm{H}$-thymidine in MLRs were compared among the groups by analysis of variance (using a general linear model) accompanied by Duncan's multiple range test (alpha set at $0.05)$.

\section{Results}

\section{Incidence of diabetes}

Experiment I: The incidence of overt diabetes in control BB rats in the Charlottesville colony by 180 days of age was found to be $68 \%(76 / 111)$, with a mean age of onset of $90 \pm 3$ days (range 51-135) (Table 2). The overall incidence of diabetes in irradiated BB rats that had received $T$-cell-depleted $W F$ bone marrow (WF $\rightarrow$ BB chimeras) was significantly reduced $(18 \%$ or $7 / 39$ animals, $p<0.001$ compared to untreated control BB rats). When the data were more closely examined, it was seen that there was zero incidence $(0 / 19$ animals) of diabetes in animals that were less than 44 days of age (40-43 days) at the time of bone marrow transfer. In the $7 \mathrm{WF} \rightarrow \mathrm{BB}$ rats that did develop diabetes, 4 were around 98 days of age at time of WF bone marrow transfer and developed diabetes at $123 \pm 6$ days of age (range 112-140), while 3 were around 51 days of age at time of transfer and developed diabetes at $75 \pm$ 3 days of age (range 71-82). Thus, in these 7 prediabetic rats, irradiated and reconstituted at different ages, the disease occurred within 22-23 days following transfer of WF bone marrow.

New breeders were obtained prior to Experiment II (Table 2) and a somewhat reduced incidence of diabetes $(53 \%$ or $29 / 52$ rats) was observed in the colony, with a mean age of onset of disease of $98 \pm$ 4 days of age (range 60-141). Of the 21 irradiated BB recipients of bone marrow from overtly diabetic $\mathrm{BB}$ rats (BB $\rightarrow$ BB; Table 2), 5 animals, or $24 \%$, became diabetic, an incidence not significantly different $(p<0.50)$ than the incidence $(8 / 21$, or $38 \%)$ in their untreated BB littermates. As in Experiment $I$, there was zero incidence of diabetes $(0 / 13)$ in $\mathrm{BB}$ recipients of T-cell-depleted WF bone marrow (WF $\rightarrow B B$ ), all of which were irradiated and treated between 37 to 41 days of age (Table 2). When the $\mathrm{WF} \rightarrow \mathrm{BB}$ chimeras treated at $<$ 44 days of age in Experiment I were combined with the WF $\rightarrow$ BB chimeras from Experiment II $(n=32)$, the reduction in incidence of diabetes compared with the $\mathrm{BB} \rightarrow \mathrm{BB}$ irradiation controls was significant at the level of $p<0.007$. Thus, BB rats lethally irradiated and reconstituted with normal bone marrow clearly developed diabetes less frequently than BB rats lethally irradiated and reconstituted with $\mathrm{BB}$ bone marrow.

Although the incidence of diabetes in $\mathrm{BB} \rightarrow \mathrm{BB}$ chimeras was not significantly different than in their litter-

Table 2. Incidence of diabetes in control and experimental BB rats

\begin{tabular}{|c|c|c|}
\hline $\mathrm{BB}$ rats & $\begin{array}{l}\text { Incidence of } \\
\text { diabetes }^{\mathrm{a}}\end{array}$ & $\begin{array}{l}\text { Age at onset } \\
\text { (days) }\end{array}$ \\
\hline \multicolumn{3}{|l|}{ Experiment I: } \\
\hline Total colony (untreated) & $76 / 111=68 \%$ & $90 \pm 3$ \\
\hline $\begin{array}{r}\mathrm{WF} \rightarrow \mathrm{BB} \text { irradiation chimeras } \\
\text { treated at }>46 \text { days of age } \\
\text { treated at }<44 \text { days of age }\end{array}$ & $\begin{array}{l}7 / 39=18 \% 0^{\mathrm{b}} \\
7 / 20=35 \% 0^{\mathrm{c}} \\
0 / 19=0 \% 0^{\mathrm{b}, \mathrm{h}}\end{array}$ & $\begin{array}{c}103 \pm 10 \\
-\end{array}$ \\
\hline \multicolumn{3}{|l|}{ Experiment II: } \\
\hline Total colony (untreated) & $29 / 52=53 \%$ & $98 \pm 4$ \\
\hline Litter-matched controls & $8 / 21=38 \%{ }^{\mathrm{d}}$ & $94 \pm 4$ \\
\hline $\begin{array}{l}\mathrm{BB} \rightarrow \mathrm{BB} \text { irradiation controls } \\
\text { (All treated at }<42 \text { days of } \\
\text { age) }\end{array}$ & $5 / 21=24 \%^{\mathrm{e}}$ & $122 \pm 2^{f}$ \\
\hline $\begin{array}{l}W F \rightarrow B B \text { irradiation chimeras } \\
\text { (All treated at }<42 \text { days of } \\
\text { age) }\end{array}$ & $0 / 13=0 \% \mathrm{gh}$ & - \\
\hline
\end{tabular}

Rats are as described in Table 1. a number of diabetic/total number of rats; ${ }^{b} p<0.001$ compared with untreated controls; ${ }^{c} p<0.006$ compared with untreated controls; ${ }^{\mathrm{d}} \mathrm{NS}(p>0.4)$ compared with total colony; ${ }^{\mathrm{e}} \mathrm{NS}(p>0.5, p>0.06)$ compared with litter-matched controls and with total colony, respectively; ${ }^{\mathrm{f}} p<0.001$ compared with age of onset in untreated littermates; ${ }^{\mathrm{g}} p<0.01, p<0.001$, compared with litter-matched controls and with total colony, respectively; ${ }^{\mathrm{h}} p<0.007$ for $\mathrm{WF} \rightarrow \mathrm{BB}$ chimeras treated at $<44$ days of age $(n=32$, pooled from Expts. I and II) compared with $\mathrm{BB} \rightarrow \mathrm{BB}$ irradiation controls 


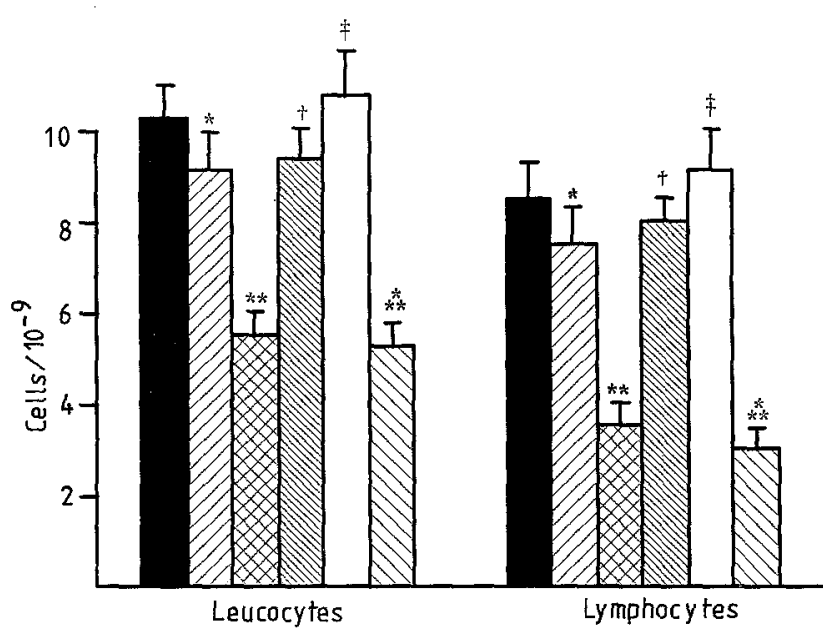

Fig. 1. Total leucocyte counts and differential cell counts were performed on peripheral blood from normal WF rats (A), WF rats lethally irradiated and injected with T-cell-depleted WF bone marrow (B), control BB rats (C), WF rats irradiated and injected with T-celldepleted MHC-compatible BB bone marrow (D), BB rats irradiated and injected with T-cell-depleted WF bone marrow (E), and BB rats irradiated and injected with.T-cell-depleted BB bone marrow $(\mathrm{F})$. Results are expressed as means \pm SEM. No differences from normal were seen in other cell types, e.g. segmented cells, eosinophils. Analyses were conducted at time of killing, 140-180 days of age for nondiabetic rats or within 20 days after appearance of glycosuria in diabetic rats. ${ }^{*} \mathrm{NS}(p \geq 0.44)$ compared with WF controls. ${ }^{* *} p<$ 0.0001 compared with WF controls; NS $(p \geq 0.61)$ compared with $\mathrm{BB} \rightarrow \mathrm{BB}$ controls. $+\mathrm{NS}(p \geq 0.63)$ compared with $\mathrm{WF}$ and $\mathrm{WF} \rightarrow \mathrm{WF}$ controls; $p<0.01$ compared with $\mathrm{BB}$ and $\mathrm{BB} \rightarrow \mathrm{BB}$ controls. $\neq$ NS ( $p \geq 0.25$ compared with WF and WF $\rightarrow$ WF controls; $p \leq 0.0001$ compared with $\mathrm{BB}$ and $\mathrm{BB} \rightarrow \mathrm{BB}$ controls. * $p<0.0001$ compared with WF controls; NS ( $p \geq 0.44$ ) compared with BB controls. WF Controls $n=18$; $\triangle \mathrm{WF} \rightarrow \mathrm{WF}$ Chimeras $n=5$; BB Controls $n=20$; $\mathrm{BB} \rightarrow \mathrm{WF}$ Chimeras $n=5 ; \square \mathrm{WF} \rightarrow \mathrm{BB}$ Chimeras $n=18$; $\triangle \mathrm{BB} \rightarrow \mathrm{BB}$ Chimeras $n=18$

matched controls, the mean age of onset of the diabetes in the $\mathrm{BB} \rightarrow \mathrm{BB}$ chimeras was $122 \pm 2$ days of age (range $115-129$ ), a noticeable delay $(p<0.001$ by twotailed t-test). This delayed onset was not seen, however, in irradiated BB rats given WF bone marrow (Experiment I, animals treated at $>46$ days of age), in which diabetes occurred as early as at 71 days of age. It should be noted that the recipients were irradiated in identical manner in both experiments.

At no time did irradiated WF recipients of $B B$ $(\mathrm{BB} \rightarrow \mathrm{WF})$ or $\mathrm{WF}$ (WF $\rightarrow \mathrm{WF}$ chimeras) bone marrow develop disease (data not shown).

At time of killing, the mean nonfasting serum glucose value for insulin-treated diabetic BB rats (experimental and control) was $31 \pm 1 \mathrm{mmol} / \mathrm{l}(n=17)$; no significant differences were observed between experimental groups, nor between experimental and control groups. The mean nonfasting serum glucose value for WF rats was $8 \pm 0.4 \mathrm{mmol} / 1(n=18)$; that for nondiabetic experimental $\mathrm{BB}$ rats was $8 \pm 0.3 \mathrm{mmol} / 1(n=33)$. No significant differences were observed between experimental groups, nor between experimental and control groups.

\section{Lymphopoenia}

Normal WF rats had a mean leucocyte count of $10.2 \times 10^{9} / 1,85 \%$ of which were lymphocytes (Fig.1). Control BB rats with recent-onset diabetes were markedly leucopoenic and lymphopoenic, with a mean of only $5.5 \times 10^{9}$ leucocytes $/ 1(55 \%$ of normal) and a mean of only $3.6 \times 10^{9}$ lymphocytes $/ 1$ ( $42 \%$ of normal). Both leucocyte and lymphocyte counts were significantly lower than those for WF rats $(p<0.001$ for both parameters by analysis of variance). Values essentially identical to those in WF rats were seen not only in $\mathrm{WF} \rightarrow \mathrm{WF}$ irradiation controls, but also, interestingly, in $\mathrm{BB} \rightarrow \mathrm{WF}$ irradiation chimeras.

$\mathrm{BB}$ rats that had been lethally irradiated and given T-cell-depleted WF bone marrow $(\mathrm{WF} \rightarrow \mathrm{BB})$ did not demonstrate leucopoenia or lymphopoenia, as measured by leucocyte counts or lymphocyte counts $(106 \%$ of normal) in peripheral blood. This indicates that the transfer of T-cell-depleted bone marrow cells into these animals after irradiation completely corrected their lymphopoenia as well as prevented the onset of overt diabetes.

In contrast to the $\mathrm{BB} \rightarrow \mathrm{WF}$ and $\mathrm{WF} \rightarrow \mathrm{BB}$ chimeras, leucocyte and lymphocyte counts in the $\mathrm{BB} \rightarrow \mathrm{BB}$ rats were depressed and similar to those of the untreated $\mathrm{BB}$ control rats.

In all $\mathrm{WF} \rightarrow \mathrm{BB}$ chimeras tested, spleen cells were positive for the RT-7.2 differentiation alloantigen, verifying the persistence of donor-origin lymphoid cells. In our hands, the percentage of spleen cells positive for RT-7.2 alloantigen was $32 \pm 2 \%$ in WF rats $(n=6)$, $3 \pm 1 \%$ in $\mathrm{BB}$ control rats $(n=5), 3 \pm 1 \%$ in $\mathrm{BB} \rightarrow \mathrm{BB}$ chimeras $(n=2)$, and $28 \pm 2 \%$ in $\mathrm{WF} \rightarrow \mathrm{BB}$ chimeras $(n=8)$. The difference in percent positive cells between WF rats and $\mathrm{WF} \rightarrow \mathrm{BB}$ chimeras was not significant $(p=0.20)$.

The percentage of segmented cells varied among the groups; however, the differences in absolute numbers of segmented cells were not statistically significant $(p>0.60$, data not shown). No differences between control WF, control $\mathrm{BB}$, and any of the experimental groups were found in the percentages of monocytes, basophils, or eosinophils.

\section{Subset analyses of spleen cells}

Table 3 shows the results of lymphocyte subset analyses on spleen cells from control and experimental animals. In normal WF rats (Column A), the fraction of the total spleen cells that were of the $\mathrm{W} 3 / 25^{+}$and $\mathrm{OX}^{+}$subsets were approximately equal: $25.1 \%$ and $22.5 \%$, respectively. The sum of these two subsets $(47.6 \%)$ was essentially equal to that seen with a $1: 1$ mixture of the W3/25 and OX8 antibodies (46.2\%) and with each of the W3/13 (45.9\%) and OX19 $(38.7 \%)$ antibodies, suggesting that the $\mathrm{W} 3 / 25^{+}$and $\mathrm{OX} 8^{+}$subsets do not overlap appreciably and adequately account for all T-cells in the normal WF rat. 
Table 3. Lymphocyte subset analyses of spleen cells from control WF and BB rats and from irradiation chimeras

\begin{tabular}{|c|c|c|c|c|c|c|}
\hline Cell Type & A & B & $\mathrm{C}$ & $\mathrm{D}$ & $\mathrm{E}$ & $\mathrm{F}$ \\
\hline & $\begin{array}{l}\text { WF } \\
n=19\end{array}$ & $\begin{array}{l}\mathrm{WF} \rightarrow \mathrm{WF} \\
n=6\end{array}$ & $\begin{array}{l}\text { Recent-onset } \\
\text { diabetic BB } \\
n=18\end{array}$ & $\begin{array}{l}\mathrm{BB} \rightarrow \mathrm{WF} \\
n=8\end{array}$ & $\begin{array}{l}\mathrm{WF} \rightarrow \mathrm{BB} \\
n=13\end{array}$ & $\begin{array}{l}\mathrm{BB} \rightarrow \mathrm{BB} \\
n=15\end{array}$ \\
\hline B-lymphocytes $\left(\mathrm{Ig}^{+}\right)$ & $44.9 \pm 0.9$ & $41.4 \pm 0.6$ & $50.3 \pm 2.1$ & $41.0 \pm 0.8$ & $41.9 \pm 2.2$ & $57.4 \pm 2.6$ \\
\hline $\mathrm{W} 3 / 13^{+}(\mathrm{T}-$ cells $)$ & $45.9 \pm 1.3$ & $44.4 \pm 1.7$ & $27.9 \pm 1.4^{\mathrm{a}, \mathrm{b}}$ & $41.2 \pm 1.3^{\mathrm{c}, \mathrm{d}, \mathrm{e}}$ & $31.8 \pm 1.5^{a, f}$ & $25.5 \pm 2.2$ \\
\hline $\mathrm{W} 3 / 25^{+}\left(\mathrm{T}_{\mathrm{h}} / \mathrm{T}_{\mathrm{i}}\right)$ & $25.1 \pm 0.5$ & $28.1 \pm 0.3$ & $10.2 \pm 0.7^{\mathrm{a}, \mathrm{e}}$ & $27.2 \pm 0.8^{\text {d, e, g }}$ & $16.1 \pm 0.9^{\mathrm{a}, \mathrm{d}, \mathrm{e}}$ & $12.8 \pm 0.9$ \\
\hline $\mathrm{OX}^{+}\left(\mathrm{T}_{\mathrm{c}} / \mathrm{T}_{\mathrm{s}} / \mathrm{NK}\right)$ & $22.5 \pm 0.8$ & $20.3 \pm 0.5$ & $6.5 \pm 0.7^{\mathrm{a}, \mathrm{d}, \mathrm{e}}$ & $20.3 \pm 0.7^{\mathrm{d}, \mathrm{e}, \mathrm{h}}$ & $11.7 \pm 0.9^{\mathrm{a}, \mathrm{d}, \mathrm{i}}$ & $9.2 \pm 0.8$ \\
\hline $\mathrm{W} 3 / 25^{+}+\mathrm{OX}-8^{+\mathrm{j}}$ & $46.2 \pm 1.0$ & $52.0 \pm 1.5$ & $16.2 \pm 1.1^{a, b}$ & $50.2 \pm 1.2^{\mathrm{d}, e, k}$ & $24.2 \pm 2.8^{\mathrm{a}, \mathrm{d}, \mathrm{e}}$ & $16.0 \pm 1.2$ \\
\hline $\mathrm{OX} 19^{+}$(T-cells $)$ & $38.7 \pm 1.4$ & $43.1 \pm 0.5$ & $6.0 \pm 0.6^{\mathrm{a}, \mathrm{b}}$ & $42.8 \pm 2.3^{\mathrm{d}, \mathrm{e}, \mathrm{k}}$ & $17.5 \pm 2.2^{\mathrm{a}, \mathrm{d}, \mathrm{e}}$ & $5.9 \pm 0.6$ \\
\hline
\end{tabular}

Rats were as described in Tables 1 and 2. Spleen cells were analysed on a fluorescence-activated cell sorter as described in the text. Results are expressed as the means \pm SEM of the percent of total viable leucocytes with the indicated phenotype. ${ }^{a} p<0.0001$ compared with WF or $\mathrm{WF} \rightarrow$ WF controls; ${ }^{b} \mathrm{NS}(p \geq 0.29)$ compared with $\mathrm{BB} \rightarrow \mathrm{BB}$ controls. ${ }^{\mathrm{c}} \mathrm{NS}(p>0.08, p>0.36)$ compared with WF and WF $\rightarrow$ WF controls respectively; ${ }^{\mathrm{d}} p \leq 0.007$ compared with $\mathrm{BB}$ controls; ${ }^{\mathrm{e}} p \leq 0.003$ compared with $\mathrm{BB} \rightarrow \mathrm{BB}$ controls; ${ }^{\mathrm{f}} p<0.01$ compared with $\mathrm{BB} \rightarrow \mathrm{BB}$ controls; $\mathrm{NS}$ $(p>0.09)$ compared with BB controls; ${ }^{g} \mathrm{NS}(p>0.08, p>0.52)$ compared with WF and WF $\rightarrow$ WF controls respectively; ${ }^{\text {h }}$ NS $(p>0.10, p=1.0)$ compared with WF and WF $\rightarrow \mathrm{WF}$ controls respectively; ${ }^{i} \mathrm{NS}(p>0.04)$ compared with $\mathrm{BB} \rightarrow \mathrm{BB}$ controls; ${ }^{j}$ Incubation mixture contained equal proportions of W3/25 and OX 8 monoclonal antibodies, diluted such that the final antibody concentration equalled the concentration of each individual monoclonal assayed separately; ${ }^{1} \mathrm{NS}(p>0.05, p \geq 0.48)$ compared with WF and WF $\rightarrow$ WF controls respectively

Table 4. Lymphocyte function in control WF and BB rats and irradiation chimeras

\begin{tabular}{|c|c|c|c|c|}
\hline Rat group & \multicolumn{2}{|c|}{ Responder cell type, experiment I } & \multicolumn{2}{|c|}{ Responder cell type, experiment II } \\
\hline $\mathrm{BB} \rightarrow \mathrm{WF}$ & $\begin{array}{l}53.5 \pm 1.8(6)^{\mathrm{a}, \mathrm{b}} \\
(11.4 \pm 2.4)\end{array}$ & $\begin{array}{l}78.1 \pm 3.0(3)^{a, b} \\
(3.3 \pm 0.4)\end{array}$ & & \\
\hline $\mathrm{WF} \rightarrow \mathrm{BB}$ & & & $\begin{array}{l}24.7 \pm 4.2(10)^{\mathrm{a} d} \\
(4.1 \pm 1.0)\end{array}$ & $\begin{array}{l}36.7 \pm 3.0(4)^{\mathrm{a}, \mathrm{d}} \\
(6.0 \pm 0.8)\end{array}$ \\
\hline $\mathrm{BB} \rightarrow \mathrm{BB}$ & & & $\begin{array}{l}1.0 \pm 0.1(16)^{\mathrm{c}, \mathrm{e}} \\
(6.0 \pm 0.8)\end{array}$ & $\begin{array}{l}8.5 \pm 1.8(5)^{\mathrm{c}, \mathrm{e}} \\
(3.2 \pm 1.2)\end{array}$ \\
\hline
\end{tabular}

Rats were as described in Table 1 . Spleen cells or lymph node cells were plated at $1 \times 10^{5}$ cells/well in the presence of $1 \times 10^{5}$ irradiated allogeneic (Fisher) spleen cells. Responsiveness was assessed, as described in the text, by the subsequent incorporation of ${ }^{3} \mathrm{H}$-thymidine. Results are expressed as means \pm SEM of total (uncorrected) $\mathrm{cpm} \times 10^{-3}{ }^{3} \mathrm{H}$-thymidine. Cpm $\times 10^{-3}$ observed in unstimulated responder cells (plated with medium alone) appear in parentheses under the total $\mathrm{cpm}$. Statistical analyses were performed on corrected values, after subtraction of the cpm observed in unstimulated cells. The number of animals studied in each experimental group appears in parentheses to the right of the uncorrected values. ${ }^{a}$ NS $(p>0.59)$ compared with WF controls; ${ }^{b} p<0.0001$ compared with BB controls; ${ }^{c} p<0.0001$ compared with WF controls; ${ }^{\mathrm{d}} p<0.0001$ compared with $\mathrm{BB}$ and $\mathrm{BB} \rightarrow \mathrm{BB}$ controls; ${ }^{\mathrm{e}} \mathrm{NS}(p>0.94)$ compared with $\mathrm{BB}$ controls

In recent-onset diabetic (control) BB rats, a significant decrease in $\mathrm{W} 3 / 13^{+}$T-cell frequency was seen $(27.9 \%$, or $61 \%$ of normal, $p<0.0001$ ) (Column C). This decrease was reflected in both T-cell subsets, although there was an apparent preferential depression in the $\mathrm{OX}^{+}$subset. An even more striking decrease was seen in the $\mathrm{OX} 19^{+}$subset.

Irradiated WF rats that received T-cell-depleted bone marrow from diabetic BB rats (Column D) showed virtually complete normalisation of their T-cell subset distributions, as did the irradiated WF rats that received T-cell-depleted WF bone marrow (Column B).

Surprisingly, irradiated BB rats that received T-celldepleted WF bone marrow (Column E) did not show complete normalisation of their T-cell subset distributions, despite the observation that these animals had no diabetes, yet had normal leucocyte and lymphocyte counts in peripheral blood. The fractions of cells in the $\mathrm{W} 3 / 25^{+}$and $\mathrm{OX}^{+}$subsets were significantly increased compared to control BB rats $(p<0.0001)$. However, both subsets were still significantly decreased compared to WF and WF $\rightarrow \mathrm{WF}$ control animals $(p<0.0001)$. The proportion of $\mathrm{W} 3 / 13^{+}$cells was only slightly greater $(p<0.09)$ than that of control diabetic BB rats (Column C). The partial restoration of the $\mathrm{W} 3 / 25^{+}$and $\mathrm{OX} 8^{+}$subsets is in contrast to the lack of restoration seen when nonirradiated neonatal BB rats were injected with T-cell-depleted WF bone marrow [6]. 


\section{Lymphocyte function}

The results of lymphocyte functional analyses are given in Table 4. The table lists total (uncorrected) cpm of ${ }^{3} \mathrm{H}$-thymidine incorporation in 5-day MLR assays. Statistical analyses were performed on corrected values, obtained by subtraction of the cpm observed in unstimulated cells plated in medium alone. (In Table 4, the cpm observed in unstimulated cells appear in parentheses below the uncorrected values.) Lymph node cells and spleen cells from WF rats irradiated and given $\mathrm{BB}$ bone marrow demonstrated normal responsiveness compared with lymphocytes from control WF rats $(p>0.59)$. More importantly, the lymphocytes of irradiated $\mathrm{BB}$ rats that received WF bone marrow, in which no diabetes occurred, also showed complete restoration of responsiveness ( $p>0.60$ compared with WF control rats).

\section{Discussion}

The results presented here are somewhat paradoxical. When normal WF rats were irradiated and injected with lymphoid stem cells from overtly diabetic BB rats $(B B \rightarrow W F$ chimeras), these animals showed no diabetes, normal leucocyte counts and differentials in the peripheral blood, normal $\mathrm{T}$-cell subset distributions in the spleen, and normal lymphocyte function as assessed by responses to allogeneic splenocytes. Together, these results suggest that BB rat lymphoid stem cells differentiated in an apparently normal fashion in the WF host. Since the $\mathrm{BB} \rightarrow \mathrm{WF}$ and the $\mathrm{BB} \rightarrow \mathrm{BB}$ chimeras differ only in the differentiative environment (i.e. the stem cells are the same, both BB), it appears that BB stem cells do not express a dominant defect that leads to lymphopoenia and diabetes, and suggests there is a defect in the differentiative environment. On the other hand, diabetes-prone $\mathrm{BB}$ rats that were irradiated and injected with lymphoid stem cells from normal WF rats (WF $\rightarrow B B$ chimeras) showed a marked decrease in incidence of diabetes (with zero incidence in animals treated at less than 44 days of age). They also demonstrated normal leucocyte counts and differentials in peripheral blood, and normal lymphocyte function as assessed by response to allogeneic splenocytes. Since the $\mathrm{WF} \rightarrow \mathrm{BB}$ and $\mathrm{BB} \rightarrow \mathrm{BB}$ chimeras differ only in their stem cells (i.e. the differentiative environment is the same) and since these findings show that there is a difference in the way $B B$ and WF stem cells differentiate in the $\mathrm{BB}$ rat, there must be a defect in the BB rat stem cell population. The partial restoration of lymphocyte subsets in $\mathrm{WF} \rightarrow \mathrm{BB}$ rats supports defects at the level of both the stem cell and the differentiative environment.

Note that diabetes occurred in the $B B \rightarrow B B$ chimeras in this study. The incidence of diabetes in the these chimeras was not significantly reduced compared with the incidence in their untreated BB littermates. The
$\mathrm{BB} \rightarrow \mathrm{BB}$ chimeras developed diabetes with a delayed age of onset, but the animals were followed for a sufficient period of time (until 180 days of age) to ensure ascertainment of diabetes in all of the animals of this cohort (no animals developed diabetes after 129 days of age). In contrast to the $\mathrm{BB} \rightarrow \mathrm{BB}$ chimeras, the $\mathrm{WF} \rightarrow \mathrm{BB}$ chimeras did not have a delayed onset of the disease. Indeed, the group irradiated and reconstituted at around 50 days of age actually developed diabetes at an earlier than expected age. The kinetics of diabetes onset in irradiation chimeras may be a consequence of the period of time required for the bone marrow inoculum to immunologically reconstitute the host. The delayed onset of diabetes in the $\mathrm{BB} \rightarrow \mathrm{BB}$ chimeras, not seen in $\mathrm{WF} \rightarrow \mathrm{BB}$ chimeras, might be explained by a longer time requirement for T-cell-depleted BB bone marrow cells to reconstitute a host compared with T-cell-depleted WF bone marrow cells.

We cannot rule out the possibility that irradiation in the present study may have had a partial suppressive effect on diabetes incidence, not seen in this small study but perhaps observable in a larger study. In earlier studies, whole-body irradiation of BB rats was reported to cause decreased incidence of diabetes [22]; however, irradiation was not followed in that study by immunologic reconstitution, and the high morbidity and mortality observed in the animals make interpretation of the results difficult. In contrast, Rossini, et al. [35] found that total lymphoid irradiation of BB rats at a dose of 1600 rads did not decrease frequency of diabetes.

The results of the present study are in part consistent with, and in part in contrast to, a study by Francfort, et al. [36]. In their study, irradiated diabetes-prone $\mathrm{BB}$ rats were injected with T-cell-depleted bone marrow from non-diabetes-prone BB rats. These chimeras showed a T-cell subset distribution equivalent to the non-diabetes-prone BB control rats. In contrast, our analogous $\mathrm{WF} \rightarrow \mathrm{BB}$ rats, although showing normal leucocyte and lymphocyte counts, had T-cell subset levels intermediate between those of the WF and BB control rats. It should be noted that lymphocyte subset distributions were assessed in different tissues in the two studies. More interesting, however, is the possibility that the non-diabetes-prone line used by Francfort, et al. [36] has a normal stem cell population but a defective T-cell differentiative environment (rendering them comparable to our WF $\rightarrow$ BB chimeras) leading to a low but significant incidence of diabetes. The number of rats used in their studies was insufficient to measure incidence of disease and the number used in our studies was insufficient to detect a very low incidence (1 to $5 \%$ ) of diabetes.

Bone marrow chimeras are routinely constructed in adult rats by lethal irradiation and repopulation with bone marrow cells from another strain. In the present study, FACS analyses demonstrated the presence of donor-derived WF $\left(\mathrm{RT} 7.2^{+}\right.$) lymphocytes surviving at 
least 120 days (until time of killing) in the spleens of $\mathrm{BB}$ recipients of WF bone marrow stem cells. By treating the bone marrow of the donor with anti-T-cell antiserum plus complement before repopulating the recipient, one can prevent the potential for graft-versus-host $(\mathrm{GVH})$ reaction and induce stable chimerism in fully allogeneic irradiation chimeras $[37,38]$. We cannot rule out the possibility of a subclinical or delayed $\mathrm{GVH}$ reaction in our chimeras; however, our $\mathrm{WF} \rightarrow \mathrm{BB}$ and $\mathrm{BB} \rightarrow \mathrm{WF}$ chimeras showed no clinical signs (ruffled fur, hunched back, diarrhea, etc.) of GVH reaction and continued to gain weight after the cell infusion.

The lymphocyte-responsiveness of $\mathrm{WF} \rightarrow \mathrm{BB}$ chimeras, as assessed by MLR, was restored to the level seen in WF lymphocytes, despite the observation that the splenic T-cell subsets in WF $\rightarrow B B$ chimeras were only partially restored. We have also observed normalisation of lymphocyte responsiveness in the presence of only partial improvement in T-cell subsets in BB rats given WF bone marrow as neonates [6], as well as in neonatally-thymectomised $\mathrm{BB}$ rats given neonatal WF thymus transplants [manuscript under editorial review]. It is known that not all T-cells respond to allogeneic or mitogenic stimulation. Therefore, normalisation of function is not necessarily directly correlated with normalisation of T-cell subset numbers as measured by surface markers.

In an earlier study [6], we reported that injection of bone marrow from normal rats into neonatal diabetesprone $\mathrm{BB}$ rats resulted in a decreased incidence of diabetes and restoration of lymphocyte responsiveness, whereas injection of T-cell-depleted bone marrow had no effect on function or disease. These results suggested that mature T-cells in the bone marrow inoculum were responsible for the prevention of diabetes in our studies [6] and in those of others [12, 19, 20]. This is in contrast to the observation in the present study that normal bone marrow depleted of mature T-cells can at least partially reconstitute an irradiated adolescent $\mathrm{BB}$ rat. In the neonatal study, the effect of the neonatal BB differentiative environment on the phenotype (i.e. incidence of diabetes and lack of restoration of T-cell subsets) of the experimental animals reconstituted with normal bone marrow is consistent with a major contribution from $\mathrm{BB}$ bone marrow-derived elements.

In summary, T-cell-depleted bone marrow from overtly diabetic BB rats differentiated in an apparently normal fashion in irradiated normal recipients, but $\mathrm{T}$ cell-depleted bone marrow from normal rats only partially restored the immunocompetence of diabetesprone BB rats. These studies, and those of others, suggest that there are two defects in the BB rat leading to diabetes and/or lymphopoenia. One of these occurs at the level of the bone marrow lymphoid stem cell while the other resides in the T-cell differentiative environment. Studies are currently underway to investigate the thymic and post-thymic compartments of T-cell differentiation to localise the site of the latter defect.

Acknowledgements. The authors thank Ms. S.M.Cranston and Ms. S.E.Adams for expert technical assistance, and the Diabetes Research and Training Center Biomathematics Core Facility of the University of Virginia for assistance in the statistical analyses. PZI insulin was generously donated by Eli Lilly and Company (Indianapolis, Ind, USA). Dr. D. L. Greiner (University of Connecticut Health Center, School of Medicine, Farmington, Conn, USA) generously provided the monoclonal RT-7.2 antibody. These studies were supported by a Pilot Feasibility Grant awarded by the University of Virginia Diabetes Research and Training Center, and by National Institutes of Health grant RO1-AM34984.

\section{References}

1. Nakhooda AF, Like AA, Chappel CI, Murray FT, Marliss EB (1977) The spontaneously diabetic Wistar rat. Metabolic and morphologic studies. Diabetes 26: 100-112

2. Seemayer TA, Tannenbaum GS, Goldman H, Colle E (1982) Dynamic time course studies of the spontaneously diabetic BB Wistar rat. III. Light microscopic and ultrastructural observations of pancreatic islets of Langerhans. Am J Pathol 106: 237-249

3. Logothetopoulos I, Valiquette N, Madura E, Cvet D (1984) The onset and progression of pancreatic insulitis in the overt, spontaneously diabetic, young adult BB rat studied by pancreatic biopsy. Diabetes 33: 33-36

4. Like AA, Forster RM, Woda BA, Rossini AA (1983) T-cell subsets in islets and lymph nodes of BioBreeding/Worcester (BB/ W) rats. Diabetes 32: $51 \mathrm{~A}$ (Abstract)

5. Butler L, Guberski DL, Like AA (1983) Genetic analysis of the $\mathrm{BB} / \mathrm{W}$ diabetic rat. Can J Genet Cytol 25: 7-15

6. Scott J, Engelhard VH, Curnow RT, Benjamin DC (1986) Prevention of diabetes in the BB rat. 1. Evidence suggesting a requirement for mature $T$ cells in bone marrow inoculum of neonatally injected rats. Diabetes 35: 1034-1040

7. Dyrberg T, Lernmark $\AA$, Gazdar AF (1982) Islet cell surface antibodies in spontaneously diabetic BB rats. Acta Biol Med Ger 41: 1105-1109

8. Baekkeskov S, Dyrberg T, Lernmark $\AA$ (1984) Autoantibodies to a 64-kilodalton islet cell protein precede the onset of spontaneous diabetes in the BB rat. Science 224: 1348-1350

9. Rabinowe SL, Eisenbarth GS (1984) Type I diabetes mellitus: a chronic autoimmune disease? Pediatr Clin North Am 31: 531-543

10. Yale JF, Marliss EB (1984) Altered immunity and diabetes in the BB rat. Clin Exp Immunol 57: 1-11

11. Poussier P, Nakhooda AF, Falk JA, Lee C, Marliss EB (1982) Lymphopenia and abnormal lymphocyte subsets in the "BB" rat: relationship to the diabetic syndrome. Endocrinology 110: $1825-1827$

12. Naji A, Silvers WK, Kimura H, Bellgrau D, Markham JF, Barker CF (1983) Analytical and functional studies on the T cells of untreated and immunologically tolerant diabetes-prone $\mathrm{BB}$ rats. $\mathrm{J}$ Immunol 130: 2168-2172

13. Elder ME, Maclaren NK (1983) Identification of profound peripheral $\mathrm{T}$ lymphocyte immunodeficiencies in the spontaneously diabetic BB rat. J Immunol 130: 1723-1731

14. Scott J, Engelhard VH, Benjamin DC (1984) Enhancement of mixed lymphocyte response (MLR) and mitogen stimulation in BB rat lymphocytes by IL-2 (interleukin-2). Diabetes 33 [Suppl.1]: 61 A (Abstract)

15. Like AA, Kislauskis E, Williams RM, Rossini AA (1982) Neonatal thymectomy prevents spontaneous diabetes mellitus in the BB/W rat. Science 216: 644

16. Rossini AA, Faustman D, Woda BA, Like AA, Szymanski I, Mordes JP (1984) Lymphocyte transfusions prevent diabetes in the Bio-Breeding/Worcester (BB/W) rat. J Clin Invest 74: 39-46 
17. Koevary S, Rossini AA, Stoller W, Chick W, Williams RM (1983) Passive transfer of diabetes in the $\mathrm{BB} / \mathrm{W}$ rat. Science 220: $727-728$

18. Koevary S, Williams DE, Williams RM, Stoller W, Chick WL (1985) Passive transfer of diabetes from BB/W to Wistar-Furth rats. J Clin Invest 75: 1904-1907

19. Naji A, Silvers WK, Bellgrau D, Barker CF (1981) Spontaneous diabetes in rats: destruction of islets is prevented by immunologic tolerance. Science 213: 1390-1392

20. Naji A, Silvers WK, Bellgrau D, Anderson AO, Plotkin S, Barker CF (1981) Prevention of diabetes in rats by bone marrow transplantation. Ann Surg 194: 328-338

21. Naji A, Bellgrau D, Anderson A, Silvers WK, Barker CF (1982) Transplantation of islets and bone marrow cells to animals with immune insulitis. Diabetes 31 [Suppl.4]: 84-91

22. Like AA, Rossini AA, Appel MC, Guberski DL, Williams RM (1979) Spontaneous diabetes mellitus: reversal and prevention in the $\mathrm{BB} / \mathrm{W}$ rat with antiserum to rat lymphocytes. Science 206: 1421-1423

23. Like AA, Anthony M, Guberski DL, Rossini AA (1983) Spontaneous diabetes mellitus in the $\mathrm{BB} / \mathrm{W}$ rat. Effects of glucocorticoids, cyclosporin-A, and antiserum to rat lymphocytes. Diabetes 32: 326-330

24. Like AA, Dirodi V, Thomas S, Guberski DL, Rossini AA (1984) Prevention of diabetes mellitus in the $\mathrm{BB} / \mathrm{W}$ rat with cyclosporin-A. Am J Pathol 117: 92-97

25. Laupacis A, Stiller CR, Gardell C, Keown P, Dupré J, Wallace $\mathrm{AC}$, Thibert $\mathrm{P}$ (1983) Cyclosporin prevents diabetes in BB Wistar rats. Lancet I: $10-12$

26. Benjamin DC, Scott J, Curnow RT, and Engelhard VH (1984) Stem cell vs. differentiative environment defects in the BB rat. Diabetes 33 [Suppl.1]: 11 A (Abstract)

27. Scott J, Engelhard VH, Benjamin DC (1985) The site of autoimmune defect(s) in the BB rat. Diabetes 34 [Suppl.1]: $73 \mathrm{~A}(\mathrm{Ab}$ stract)

28. Colle E, Guttmann RD, Seemayer T (1981) Spontaneous diabetes mellitus syndrome in the rat. I. Association with the major histocompatibility complex. J Exp Med 154: 1237-1242

29. Williams AF, Galfré G, Milstein C (1977) Analysis of cell surfaces by xenogeneic myeloma-hybrid antibodies: differentiation antigens of rat lymphocytes. Cell 12: 663-673
30. Brideau RJ, Carter PB, McMaster WR, Mason DW, Williams AF (1980) Two subsets of rat T lymphocytes defined with monoclonal antibodies. Eur J Immunol 10: 609-615

31. Dallman MJ, Mason DW, Webb M (1982) The roles of host and donor cells in the rejection of skin allografts by T-cell-deprived rats injected with syngeneic T cells. Eur J Immunol 12: 511-518

32. Woda BA, McFadden ML, Welsh RM, Bain KM (1984) Separation and isolation of rat natural killer (NK) cells from $T$ cells with monoclonal antibodies. J Immunol 132: 2183-2184

33. Mason DW, Arthur RP, Dallman MJ, Green JR, Spickett GP, Thomas ML (1983) Functions of rat T-lymphocyte subsets isolated by means of monoclonal antibodies. Immunol Rev 74 : $57-82$

34. Greiner DL, Handler ES, Nakano K, Mordes JP, Rossini AA (1986) Absence of $R T-6$ T cell subset in diabetes-prone $B B / W$ rats. J Immunol 136: 148-151

35. Rossini AA, Slavin S, Woda BA, Geisberg M, Like AA, Mordes JP (1984) Total lymphoid irradiation prevents diabetes mellitus in the Bio-Breeding Worcester (BB/W) rat. Diabetes 33: 543-547

36. Francfort JW, Naji A, Silvers WK, Barker CF (1985) The influence of T-lymphocyte precursor cells and thymus grafts on the cellular immunodeficiencies of the BB rat. Diabetes 34: 1134 -1138

37. Müller-Ruchultz W, Wootge HU, Müller-Mermelink HK (1976) Bone marrow transplantation in rats across strong histocompatibility barriers by selective elimination of lymphoid cells in donor marrow. Transplant Proc 8: 537-541

38. Rayfield LS, Brent L (1983) Tolerance, immunocompetence, and secondary disease in fully allogeneic radiation chimeras. Transplantation 36: 183-189

Received: 4 May 1987

and in revised form: 24 August 1987

Dr. Joanne Scott

Box 386, Department of Pediatrics

University of Virginia

School of Medicine

Charlottesville, VA 22908

USA 